\title{
A preparation of the blowfly (Calliphora erythrocephala) brain for in vitro electrophysiological and pharmacological studies
}

\author{
Tilmann M. Brotz ${ }^{1, *}$, Martin Egelhaaf ${ }^{2}$, Alexander Borst ${ }^{1}$ \\ Max-Planck-Institut für Biologische Kybernetik, Spemannstrasse 38. D-72076 Tübingen, Germany \\ Received 5 January 1994; revised 6 July 1994; accepted 7 July 1994
}

\begin{abstract}
We describe a method for the preparation and maintenance of the blowfly (Calliphora erythrocephala) brain in a recording chamber under in vitro conditions in a semi-slice configuration. Large identified neurones in the posterior part of the 3rd optic lobe (lobula plate) can be penetrated easily with microelectrodes. The so-called vertical system (VS) cells which respond to vertical image motion in vivo could be encountered best because their axons are escorted individually by specific tracheae. Fluorescent stained cells show their natural shape as being in vivo. Electrophysiological properties of the cells investigated so far, i.e., resting potential (about $-40 \mathrm{mV}$ ) and firing properties (single rebound spikes), are comparable to recordings in intact flies. Initial pharmacological experiments on VS cells in this preparation reveal that iontophoretical application of acetylcholine and carbamylcholine results in depolarization. VS cells also respond to bath-applied nicotine $(1 \mu \mathrm{M})$ with a slow depolarization of their membrane potential in normal fly saline as well as in a $\mathrm{Ca}^{2+}$-free saline, suggesting direct cholinergic input via nicotinic receptors. The suitability of the preparation for a wide range of electrophysiological and pharmacological studies is discussed.
\end{abstract}

Keywords: Insect brain; In vitro; Motion detection; Identified neurone; Visual system; Technique

\section{Introduction}

The fly is an important model system for investigations concerning visual motion processing and the use of motion cues for visual course control. Behavioral, anatomical, electrophysiological and computational studies have revealed some of the mechanisms underlying the evaluation of visual motion information in the fly's brain (Fermi and Reichardt, 1963; Götz, 1964; Buchner, 1984; Hausen, 1984; Egelhaaf et al. 1988; Borst and Egelhaaf, 1989; Strausfeld, 1989). In this context, a sample of about 50 neurones in the posterior part of the 3rd optic lobe, the lobula plate, play a key role. With their large dendrites they are presumed to

\footnotetext{
*Corresponding author. Tel.: (49) 7071-601-842; Fax: (49) 7071601-455.

${ }^{1}$ Present address: Friedrich-Miescher-Laboratorium der MaxPlanck-Gesellschaft, Spemannstrasse 37-39, D-72076 Tübingen, Germany.

${ }^{2}$ Present address: Australian National University, School for Biological Sciences, Visual Science Center, PO BOX, Canberra, ACT 2601, Australia.
}

integrate the output signals of a 2-dimensional array of local motion-sensitive elements. Although the anatomy and response characteristics of these individually identifiable cells are well characterized there is a substantial lack in understanding the ionic basis of their passive and active membrane properties, as well as the pharmacology of their transmitter receptors. This study concentrates on a subset, the so-called vertical system (VS) cells, which are sensitive to vertical image motion. VS cells do not show spontaneous spikes nor do they respond with full-blown action potentials to vertical image motion (Hengstenberg, 1982a). Instead, they respond with small fast and active depolarizations superimposed on graded potential modulations. Full-blown action potentials can be elicited only from a hyperpolarized state (Hengstenberg, 1977; Haag et al. 1993). Furthermore, the origin of recently discovered calcium signals in response to motion stimuli detected by in vivo imaging in these and other tangential cells remains to be clarified (Borst and Egelhaaf, 1992). To answer these questions we decided to develop an in vitro preparation of the blowfly (Calliphora erythrocephala) brain to enable in vitro approaches under defined 
conditions in terms of ion concentrations and pharmacological agents. In such a preparation the visual interneurones in the lobula plate should be accessible for recording, still identifiable and susceptible for neuropharmacological treatment. We present a new method for an acute semi-slice preparation of the fly brain and demonstrate its suitability for electrophysiological and pharmacological studies. The properties of VS cells in vitro are compared with those of VS cells in intact flies with respect to their morphology and physiology. In addition, initial pharmacological findings are shown, suggesting cholinergic receptors as excitatory input channels on VS cell dendrites.

\section{Materials and Methods}

\subsection{Preparation}

All experiments were carried out with female blowflies from the laboratory stock. Since freshly eclosed flies are too soft for preparation and older flies have a hard cuticula and neural sheath the age of flies was choosen 1-3 days after eclosion. Dissection was done in ice-cold fly saline $(110.0 \mathrm{mM} \mathrm{NaCl}, 5.4 \mathrm{mM}$ $\mathrm{KCl}, 1.9 \mathrm{mM} \mathrm{CaCl}, 20.0 \mathrm{mM} \mathrm{NaHCO} 3,15.0 \mathrm{mM}$ TRIS, $13.9 \mathrm{mM}$ glucose, $73.7 \mathrm{mM}$ sucrose, $23.0 \mathrm{mM}$ fructose, adjusted to $\mathrm{pH} 7.2$ at $25^{\circ} \mathrm{C}$ with $1 \mathrm{~N} \mathrm{HCl}$ ). Sucrose and fructose were added to reach a osmolarity of about $400 \mathrm{mOsm}$, comparable to the osmotic pressure of the fly hemolymph (Normann, 1973). All components were obtained from Sigma (Deisenhofen, Germany) and were cell-culture tested with the exception of TRIS buffer.

A cold-anaesthetised fly is decapitated and the head is fixed by insect pins in a petri dish coated with Sylgard (diameter: $35 \mathrm{~mm}$, Becton Dickinson, Heidelberg, Germany; Sylgard by Dow Corning, Seneffe, Belgium). The head capsule is opened at the rear, the proboscis is removed and the preparation rinsed 3 times with saline. All airsacs, big tracheae, muscles and glands are removed thoroughly. The preparation is rinsed again 3 times with saline. With ophtalmological scissors the first optic chiasma is cut between the lamina and medulla. The isolated brain is then transferred with a wide-mouthed transfer pipette (Becton Dickinson) to a glue chamber. The glue chamber (Fig. 1) consists of a culture plate insert with a membrane at its bottom (diameter: $30 \mathrm{~mm}$; membrane pores: 0.4 $\mu \mathrm{m}$, Millipore, Bedford, MA) and a conventional petri dish (diameter: $35 \mathrm{~mm}$, Becton Dickinson) which is also filled with ice-cold fly saline. In the glue chamber the brain is oriented with its posterior side upwards. The saline in the culture plate insert is removed completely while the brain is kept moist through the membrane. An ethanol-cleaned brass washer (useful inner diameters: $1.0-1.4 \mathrm{~mm}$ ) is cut with diagonal cutting pliers to an omega-like shape (Fig. 2A). Brass is easy to cut, not magnetizable (like stainless steel) and forms better glueing results than teflon. The washer is dipped into a drop of cyanacrylate super-glue (UHU-Sekundenkleber, Bühl, Germany). Excess glue is wiped off and the washer is slightly pressed onto the posterior surface of the brain in such a way that the lobula complex and the lateral protocerebrum remain uncovered. It is absolutely essential that the preparation is covered by as little saline as possible to prevent spreading of the glue over the entire brain. The preparation is rinsed with saline instantaneously to harden the glue and is transferred with forceps from the culture plate insert to the underlying petri dish where it is rinsed with saline several times. Optionally a wide-spaced specimen grid for electron microscopy (diameter: 3.05 mm; mesh: 50; Stork Veco, Eerbeek, Holland) can be inserted between the brain and the brass washer for enhanced mechanical stability during penetration of the preparation with electrodes. In this case, the grid has to be put onto the brain before gluing the brass washer onto it. Further handling of the preparation has to be done very carefully to avoid damaging the neurones near the posterior brain surface. The neurolemma of the anterior side of the uncovered visual system is gently peeled off. Parts of the anterior medulla and the lobula are removed to flatten the preparation (Fig. 2B). Then the preparation is immediately transferred to the recording chamber where it is perfused with prebubbled fly saline $\left(95 \% \mathrm{O}_{2}, 5 \% \mathrm{CO}_{2}\right.$; CARBOGEN, Messer-Griesheim, Frankfurt, Germany) at

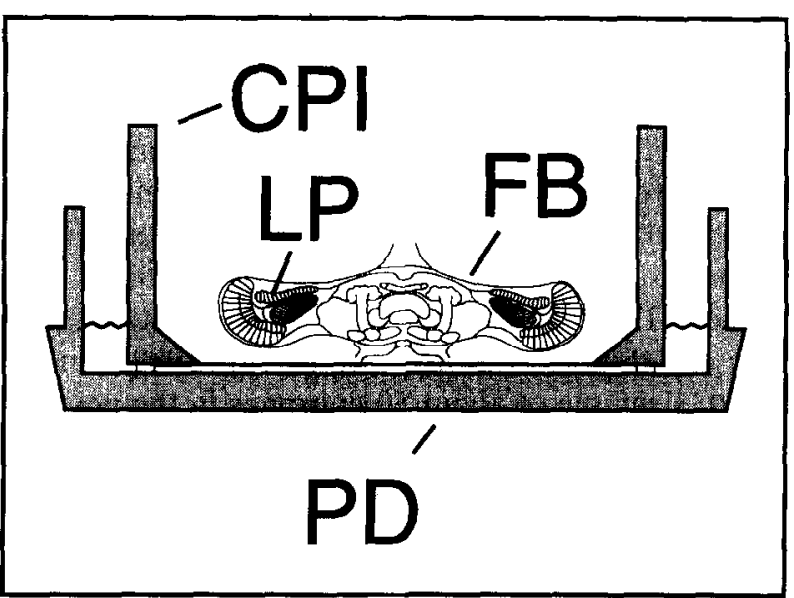

Fig. 1. Schematic, vertical section of the glue chamber with the isolated brain. The fly brain is shown in a horizontal section oriented with its posterior side faced upwards. The lumen between petri dish and culture plate insert is filled with ice-cooled fly saline keeping the brain moist through the membrane at the bottom of the culture plate insert. The brain is enlarged with respect to petri dish and culture plate insert. CPI, culture plate insert; FB, fly brain; LP, lobula plate; PD, petri dish. 
room temperature. The duration of the whole preparation should not exceed 10-15 min.

The perfusion system is driven by a peristaltic pump (IPS8, Ismatec, Wertheim, Germany). To prevent pulsations in the circulating saline a hydrostatic column of $4 \mathrm{~mm}$ inner diameter and $130 \mathrm{~mm}$ height (Hengstenberg, 1982b) is inserted into the perfusion system at the entrance of the recording chamber. The perfusion system can also be driven by gravity with an elevated saline reservoir. In this configuration the hydrostatic column is used to estimate the flow rate. The typical flow rate is about $4 \mathrm{ml} / \mathrm{min}$ which is equivalent to a total replacement of the volume of the recording chamber $(300 \mu \mathrm{l})$ within about $4 \mathrm{~s}$.
The recording chamber has a diameter of $11 \mathrm{~mm}$ and a depth of $3 \mathrm{~mm}$. The bottom is formed by a conventional coverglass which is glued to the corpus of the recording chamber with silicone (Elastosil ${ }^{\mathrm{TM}}$, Wacker-Chemie, Munich, Germany). Saline is removed by a bevelled steel tube (outer diameter: $2 \mathrm{~mm}$ ), keeping a constant, non-oscillating level of the saline in the recording chamber (Hengstenberg, 1982b) driven by the peristaltic pump. The recording chamber is mounted on an inverted microscope (Fig. 2C) (Axiovert 35M, Zeiss, Oberkochen, Germany). The preparation is observed with objectives of 10 - and 20 -fold magnification (Plan-Neofluar $10 \times / 0.30 \mathrm{Ph} 1$, LD Achroplan $20 \times / 0.40$ korr. $\mathrm{Ph} 2$, both made by Zeiss).

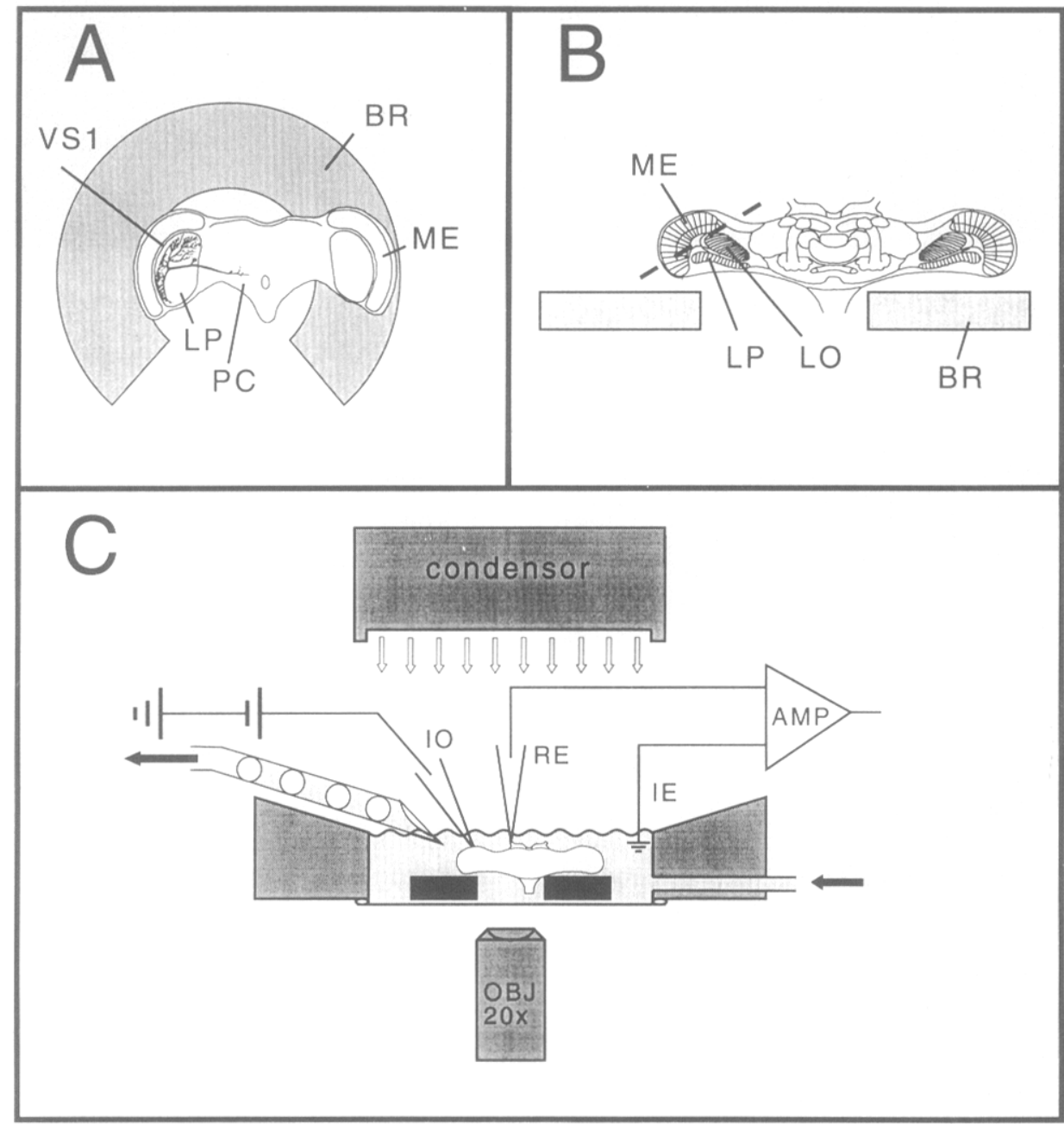

Fig. 2. Preparation and set-up. A: schematic view of the whole preparation mounted on the brass ring as seen from above. The left side of the visual system is attached only by a narrow region of the medulla to the brass ring thus leaving the left lobula plate uncovered in contrast to the right side of the visual system which is glued entirely onto the brass ring. In the left lobula plate the position of a VS1 cell is shown. B: vertical section through the preparation. The brain is therefore shown in a horizontal section. The dashed line indicates the cutting plane for the removal of parts of the anterior medulla and lobula. At this position of the brain on the brass ring the left lubula plate and lateral protocerebrum can be seen from below using an inverted microscope. C: set-up configuration. The preparation is situated in the recording chamber mounted on an inverted microscope. The lobula plate faces towards the objective with a 20 -fold magnification (see B). The recording electrode is placed in the lateral protocerebrum, while the iontophoretic electrode is situated in the lobula plate. AMP, electrophysiological amplifier; BR, brass ring; IE, indifferent electrode; IO, iontophoretic electrode; ME, medulla; LO, lobula; LP, lobula plate; OBJ, objective with 20x magnification; PC, protocerebrum; RE, recording electrode; VS1, VS1 cell. 


\subsection{Electrophysiology}

Fly neurones were penetrated under optical control in transillumination. Electrodes were pulled from borosillicate thick-walled capillaries (GC100F-10, Clark
Electromedical Instruments, Pangbourne Reading, UK) on a DMZ Universal Puller (Zeitz-Instruments, Augsburg, Germany) or a P80 Brown/Flaming Microelectrode Puller (Sutter Instrument, San Francisco, CA). They had a resistance of $40-80 \mathrm{M} \Omega$ when filled with 1

$$
\text { in vitro }
$$
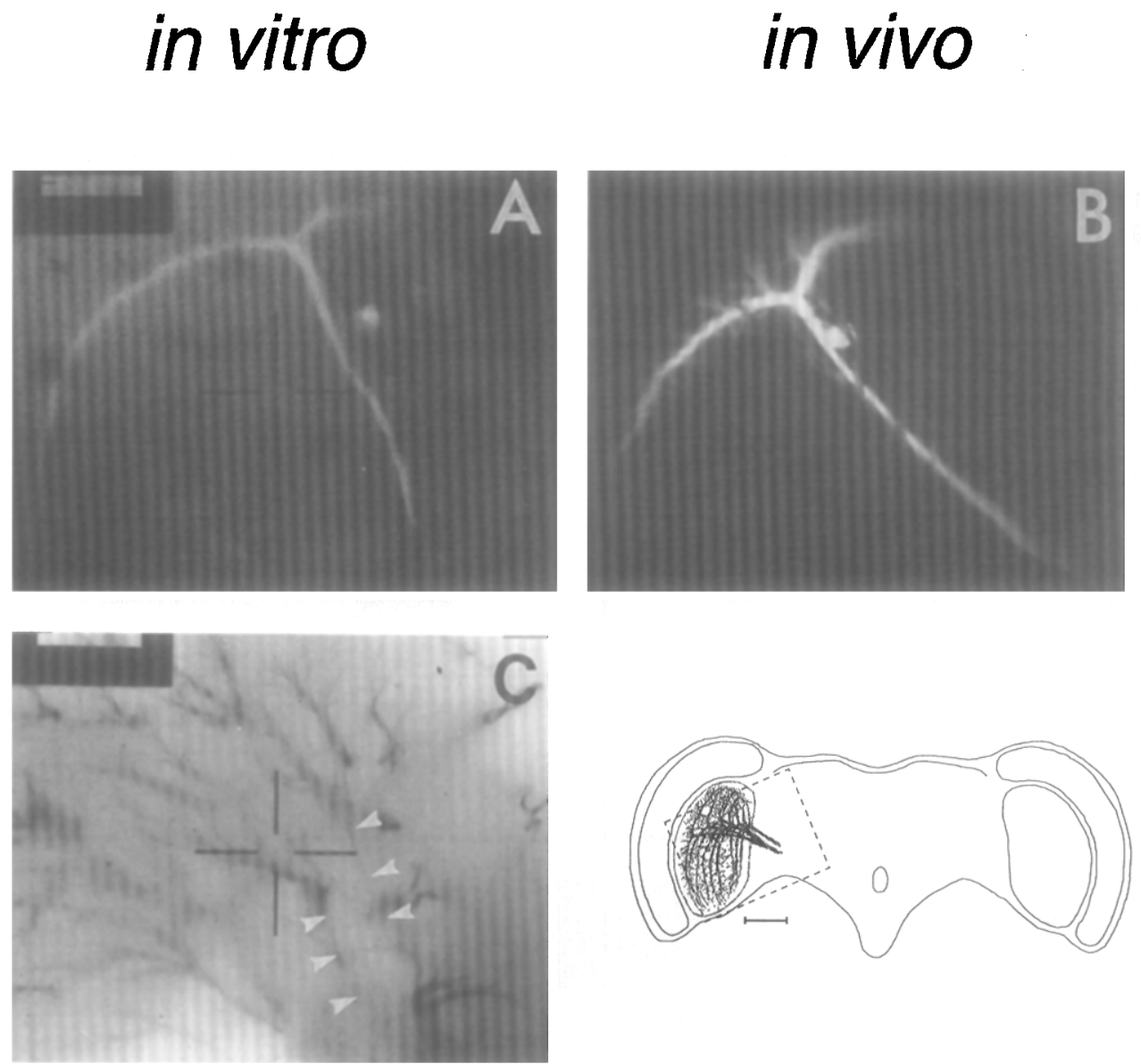

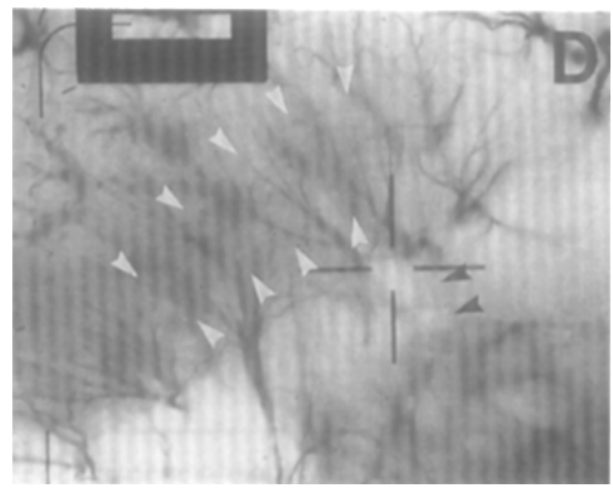

Fig. 3. Morphology of VS cells compared in the preparation and in an intact fly and visible markers for VS cell location. A: Lucifer-Yellow-stained VS cell recorded in vitro. B: stained VS cell recorded in vivo (photograph kindly provided by J. Haag). There are no apparent visible differences in the cell morphology. C: single tracheae escorting VS axons in the ventro-lateral protocerebrum (transillumination). Arrow heads mark the region of the VS axon tract. Note that the trachea marked by the right arrow heads corresponds to the VS cell shown in (A) (same scaling and position). The dashed box in the drawing shows the margins of the photograph and the position of the VS cells. Cell reconstructions from Hengstenberg et al. (1982). D: visible dendritic structures of a couple of VS cells (surrounded by white arrow heads) seen in transillumination. Black arrow heads point to visible VS cell axons. Scale bar in the upper left corners of the microphotographs is $100 \mu \mathrm{m}$ in (A) and (C); $200 \mu \mathrm{m}$ in (D) and $250 \mu \mathrm{m}$ in the drawing. 
$\mathrm{M} \mathrm{LiCl}$ and Lucifer Yellow in the tip. For current injection electrodes were treated with Sylgard (Laurent, 1990 ) and filled with $3 \mathrm{M}$ potassium acetate resulting in a resistance of $50-80 \mathrm{M} \Omega$. Bent electrode holders $\left(90^{\circ}\right.$; Clark Electromedical Instruments, Pangbourne Rcading, UK) which wcre directly inserted into the probe were used to penetrate the preparation vertically. $\mathrm{An} \mathrm{Ag} / \mathrm{AgCl}$ pellet served as an indifferent electrode (Science Products, Frankfurt, Germany). Signals were amplified by an Axoclamp 2A (Axon Instruments, Foster City, CA). Measurements of membrane potential were performed with the amplifier in bridge mode. Experiments with current injection were carried out in discontinuous current clamp mode (DCC) at sampling frequencies of $2.5-3 \mathrm{kHz}$. Electrophysiological signals were fed to an AT-compatible personal computer via an A/D-converter (DT 2801, Data Translation, Marlboro, MA) at $14 \mathrm{~Hz}$ for long-term recordings of membrane potentials and at $5 \mathrm{kHz}$ for spike recordings. Software for data acquisition and evaluation was written in ASYST (ASYST Software Technol., Rochester, NY). For latter identification cells were filled with the fluorescent dye Lucifer Yellow (Stewart, 1978). Often cells were stained sufficiently for identification even without current injection. Oth- erwise a hyperpolarizing current of -1 to $-2 \mathrm{nA}$ was injected for several minutes.

\subsection{Pharmacology}

Acetylcholine and carbamylcholine were applied iontophoretically. Thin-walled borosillicate capillaries (GC100TF-10, Clark Electromedical Instruments, Pangbourne Reading, UK) were used to pull low-resistance iontophoretic electrodes $(<10 \mathrm{M} \Omega)$. Iontophoretic electrodes were filled with a $100 \mathrm{mM}$ solution of acetylcholine chloride (Sigma) or with a $1 \mathrm{M}$ solution of carbamylcholine chloride (Sigma). To prevent leakage a retaining current of $-30 \mathrm{nA}$ was applied. The iontophoretic electrode was positioned near the dendritic arborisation of the VS cells. Nicotine (1 $\mu \mathrm{M}$, free base, Sigma) was bath-applied by a 2 -way tap which allowed switching between nicotine-containing and normal saline. The hydrostatic column was replaced by a vertical silicon tube (inner diameter: $2 \mathrm{~mm}$ ) to reduce the residual volume. In some experiments calcium ions in the fly saline were substituted by a high concentration of $\mathrm{Mg}^{2+}(20 \mathrm{mM})$ to suppress synaptic transmission. The concentration of sucrose was decreased accordingly to achieve the same osmolarity as
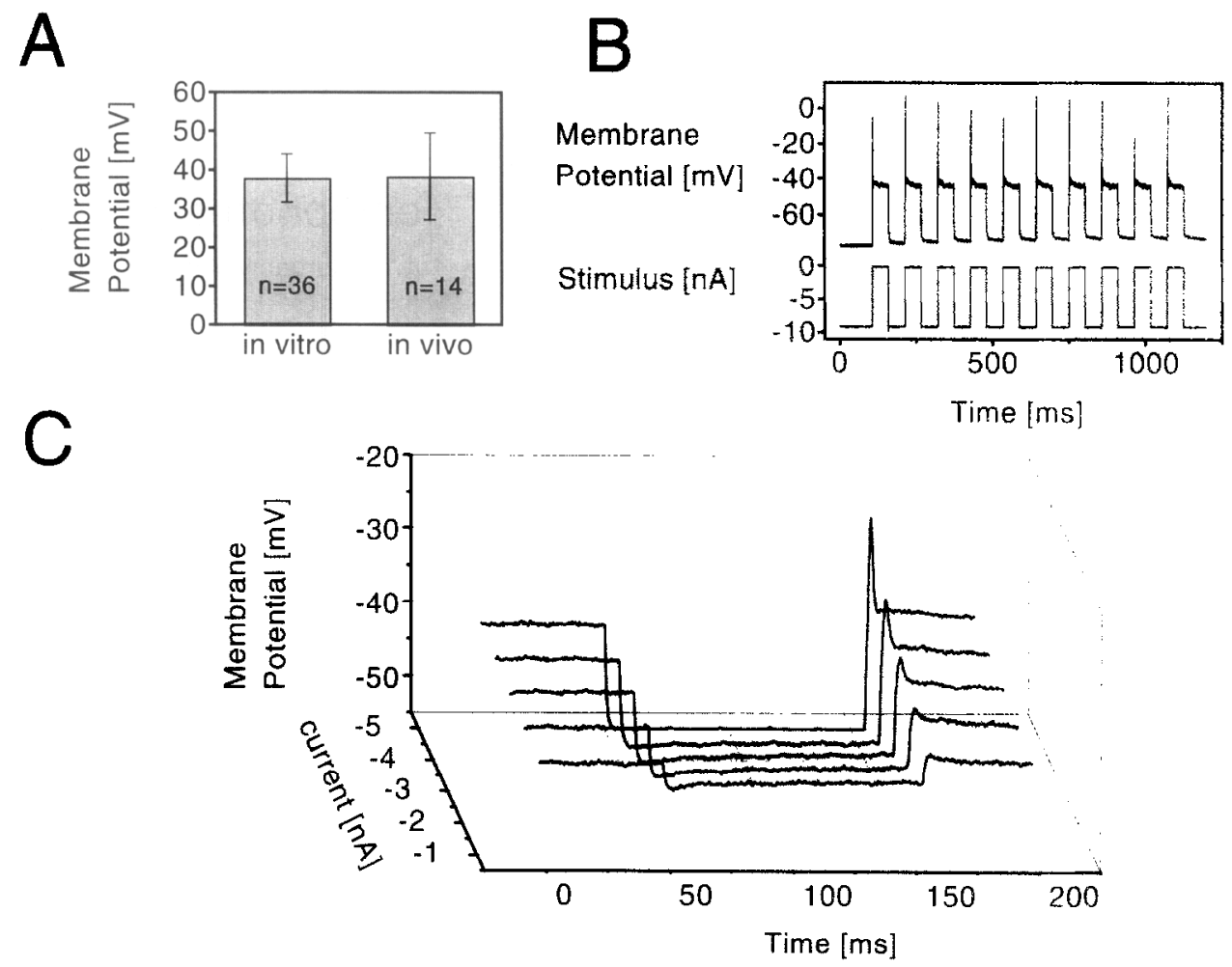

Fig. 4. Electrophysiological indications of vitality. A: resting potential in VS cells recorded in vitro and in vivo (in vivo data from Haag et al (1992), modified). B: pulse protocol for generation of rebound spikes in VS cells. The cell is held at a hyperpolarized state by injection of a negative current (here $-9 \mathrm{nA}$ ). The cell is released to rest for $50 \mathrm{~ms}$, resulting in a single spike. Then the cell is hyperpolarized for another 50 ms. This cycle is repeated 10 times. C: averaged traces of hyperpolarizing pulses with increasing amplitude. Note the development of the rebound spike with increasing hyperpolarization. 
in normal fly saline. Controls were performed with nicotine-free saline containing equal amounts of bidistilled water as the nicotinic saline. After cell recording controls were also done with nicotine-containing saline.

\section{Results}

The vitality of the preparation was examined by comparing the morphology and physiology of identified neurones with the respective features of these cells in vivo. In addition, preliminary experiments were performed on the pharmacology of the neurones' transmitter receptors.

\subsection{Morphology}

Several types of large motion-sensitive neurones of the lobula plate were recorded and stained with Lucifer Yellow. These include cells from the vertical system, the so-called VS cells (Hengstenberg et al., 1982; Hengstenberg, 1982a), cells from the horizontal system, the so called HS cells (Hausen, 1982a,b) and the so-called CH cells (Hausen, 1976; Eckert and Dvorak, 1983; Egelhaaf et al., 1993). The most frequently encountered cell types were the VS cells which, in vivo, are sensitive to vertical motion (Fig. 3A). Forty-five VS cells were stained and identified. From the 11 different VS cells described by Hengstenberg (1982), this sample comprised VS cells 1-9. Identified VS cells in the

A

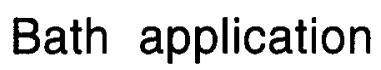

of $1 \mu \mathrm{M}$ Nicotine

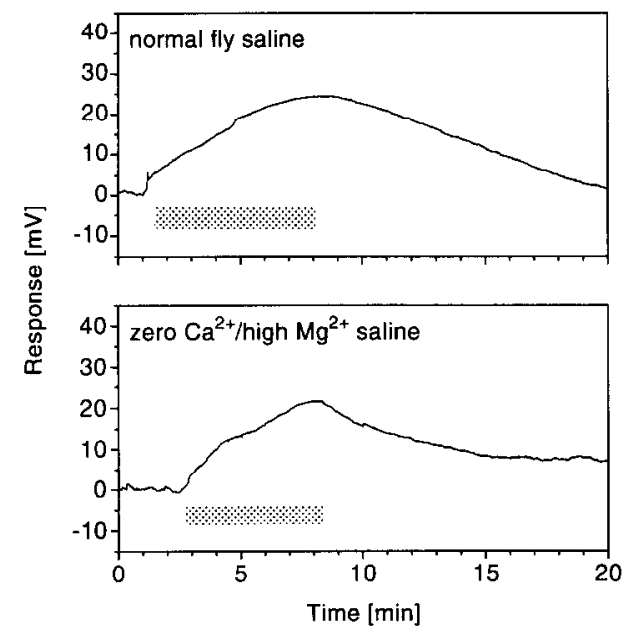

preparation turned out to be identical in their morphology to VS cells stained in intact flics (Fig. 3B). No changes of the cell shape could be detected that might be attributed to the dissection procedure. In preparations with an inserted EM grid occasionally only axon and axon terminal of VS cells were stained indicating that dendrites were squeezed by the grid. Normally, however, this was prevented by careful preparation. Axons of VS cells were found to be escorted by individual tracheae (R. Hengstenberg, personal communication). These tracheae could be seen in transillumination of the preparation in the ventro-lateral protocerebrum (Fig. 3C). Positioning of the recording electrode near such a trachea in the same focal plane allowed defined penetration of VS cell axons. Occasionally dendrites of VS cells could be observed even without staining in flat preparations where they appear as bright structures allowing dendritic recordings of VS cells (Fig. 3D).

\subsection{Physiology}

The resting potential of 36 VS cells was measured and had an average value of $-37.96 .2 \mathrm{mV}$ (mean \pm SD) as shown in Fig. 4A. This relatively low value is typical of VS cells and is in agreement with earlier studies on intact flies (Hengstenberg, 1977, 1982a; Haag et al. 1992). The input resistance was determined only in a few VS cells and was always found to be in the range of 3-5 M $\Omega$. This also is typical for VS cells in

\section{B}

\section{Iontophoresis}

of $1 \mathrm{M}$ Carbamylcholine

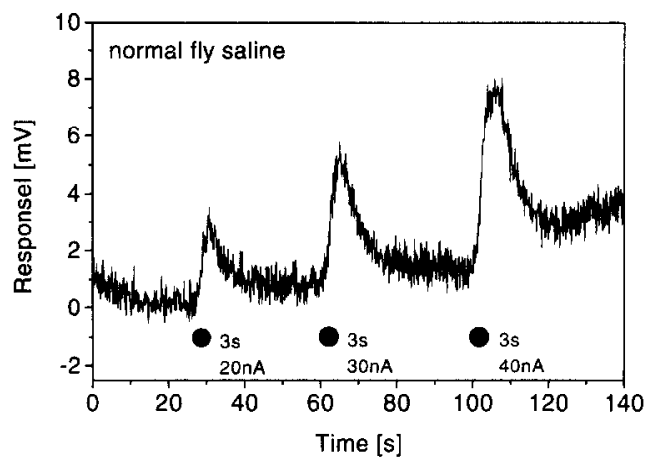

Fig. 5. Pharmacological experiments on the preparation. A: bath-application of $1 \mu \mathrm{M}$ nicotine in normal fly saline (upper box) and in $\mathrm{Ca}^{2}{ }^{2}$-free saline containing a high $\mathrm{Mg}^{2+}$ concentration $(20 \mathrm{mM})$ to suppress synaptic transmission (lower box). The VS cell depolarizes in both cases in the same manner. B: iontophoretic application of carbamylcholine. Filled dots indicate iontophoretic current pulses of different amplitudes. The VS cell depolarizes much faster due to local application near the dendritic tree than after bath application. The cell also repolarizes faster than after bath application. 
vivo (Haag et al., 1993). Compared to recordings in vivo, intracellular recordings of non-spiking neurones show a relatively smooth recording baseline.

As the VS cells lack the natural input from the eyes, they could be stimulated only by current injection. Releasing the cells from a hyperpolarized state to rest triggers single rebound spikes (Fig. 4B) of variable amplitude, depending on the previous hyperpolarizing current (Fig. 4C). Due to the relatively low input resistance of the cells, high-current intensities are necessary, i.e., -5 to $-10 \mathrm{nA}$. Again, this property was expected from experiments in vivo (Hengstenberg, 1977; Haag et al. 1993).

In almost all preparations examined, spontaneously spiking cells were recorded in the neighbourhood of VS axons, too. These cells often showed a highly regular spike frequency which varied in different cells between 40 and $80 \mathrm{~Hz}$. This is additional evidence for the vitality of the preparation. Identification of VS cells in the preparation without staining was accomplished by the following criteria: (i) penetration of the cell in the VS axon tract near an escorting trachea; (ii) resting potential in the range of -50 to $-35 \mathrm{mV}$; (iii) characteristic spiking properties as described above; and (iv) low input resistance.

\subsection{Pharmacology}

Bath application of $1 \mu \mathrm{M}$ nicotine during recording from VS cells yielded a slow depolarization of the membrane potential by about $25 \mathrm{mV}$ (Fig. 5A, upper box). The cells repolarized with a slower time course when nicotine was removed from the saline. Application of the same concentration of nicotine in a calcium-free saline with high magnesium concentration to suppress synaptic transmission depolarized the VS cells in the same manner as in normal fly saline (Fig. $5 \mathrm{~A}$, lower box) suggesting a direct effect of nicotine on receptors of VS cells. Acetylcholine did depolarize VS cells only in some cases when bath-applied $(100 \mu \mathrm{M})$, but these experiments were not reproducible. This may be due to the activity of non-specific cholinesterases found in insect neuroglia which can influence the concentration of acetylcholine in the extracellular space of the insect central nervous system (Treherne, 1985). The local, iontophoretic application of acetylcholine and carbamylcholine into the lobula plate depolarized the VS cells in a concentration-dependent manner (Fig. 5B). The time course of the iontophoretically induced responses was in the range of seconds, compared to minutes when bath-applied.

\section{Discussion}

The preparation presented in this study is with respect to its thickness of approximately $200 \mu \mathrm{m}$ com- parable to slice preparations of vertebrate nervous tissue (e.g., Edwards et al., 1989). As it consists of almost the entire brain of the fly we consider this preparation a semi-slice. The semi-slice allows recording of interneurones in the lobula plate as well as in the lateral regions of the protocerebrum and the deuterocerebrum. Different gluing positions should allow for the recording of cells also in other neuropiles, e.g., antennal lobes or mushroom bodies. Removal of the neurolemma is important for an easy insertion of the electrode into the neuropile and a better diffusion of compounds dissolved in the perfusing saline. Removal of the nerve sheath was shown to be essential for the access of pharmaceutical agents to the nerve cell membrane (Callec and Sattelle, 1973; Sattelle et al., 1976; Sattelle, 1980, 1985; Callec, 1985; Schmid, 1989). The dissection of the anterior medulla makes the preparation significantly thinner in the region of the lobula plate and enhances the visibilty of relevant structures in the lobula plate. In addition, diffusion distances for nutritional elements, oxygen and pharmacological agents become shorter. The partial loss of the medulla means a partial loss of retinotopically organized input elements to the lobula plate. As was shown, this does not alter the basic electrophysiological features of VS cells. For future experiments it is planned to leave the medulla intact and stimulate the medulla input pathways of the lobula plate neurones in order to generate postsynaptic potential via the natural input channels.

Recent studies show the possibility of dissociating adult dipteran neurones and maintaining them in vitro for a certain time (Pinnock and Sattelle, 1987; Hardie and Weckström, 1990; Hardie, 1989). These dissociated neuronal preparations are well suited for studies involving application of pharmacological agents and patch clamp recordings. Nevertheless, we decided to take the slice approach for the following reasons. First, the major point of interest for our studies are channels and receptors in dendritic and axonal regions. Dissociated somata are not necessarily equipped with the same set of receptors and channels as dendrites and axons. Secondly, the small number of the tangential neurones in the lobula plate would make it very difficult to find these dissociated somata among thousands of other dissociated somata from this neuropile. Our preparation leaves the cells morphologically intact so that receptors can be studied on the tangential cells in situ.

\subsection{State of the preparation}

The morphological and electrophysiological criteria examined so far suggest that VS cells in this preparation are in a physiological state comparable to VS cells in vivo. Stained VS cells in vitro cannot be distinguished from VS cells in vivo. So the characteristic morphology of the cells is preserved. The visible escort- 
ing tracheae of the VS cells are a valuable guide enabling the identification of VS cells without staining. Cells can be stained and identified even during recording and the ionotophoretic electrode can be positioned with precision close to the dendritic tree of the stained cell. This is a major advantage of our preparation compared to other explants of the adult insect central nervous system like the abdominal ganglion of the cockroach (Callec and Sattelle, 1973; Callec, 1985) or the thoracic ganglion of the locust (Laurent, 1990) which cannot be observed in transillumination in the microscope although this is possible for first instar and embryonic preparations (Blagburn et al., 1985).

Resting potential, spike thresholds and input resistance are virtually the same as in intact flies. The lacking fluctuations of the resting potential observed in vitro might be due to the missing visual input to the lobula plate.

Durability of the preparation for more than $2-3 \mathrm{~h}$ has not been examined extensively, so far. This, however, was not a limitation, because experiments were completed normally within less than $1 \mathrm{~h}$. After exposure to intense fluorescence to identify and photograph the cells, the preparation was discarded. Other preparations with a comparable lifetime include, e.g., the isolated thoracic ganglia from locusts described by Laurent (1990).

\subsection{Pharmacology of the tangential cells}

The preliminary results on the pharmacology of the tangential cells suggest that the VS cells might receive cholinergic input via nicotinic acetylcholine receptors. Insect nicotinic receptors have been shown to play a physiological role in various central nervous synapses in different species (Kerkut et al., 1969; Shankland et al., 1971; Sattelle et al. 1976; Goodman and Spitzer, 1980; Benson, 1988; Trimmer and Weeks, 1989). For review see Sattelle (1980). Immunohistochemically, acetylcholine was shown to be a widespread neurotransmitter in the insect CNS and, in particular, the visual system (Buchner et al., 1986; Gorczyca and Hall, 1987; Nässel, 1991). Recently Schuster et al. (1993) showed immunohistochemically the distribution of a ligand-binding and a structural subunit of the nicotinic acetylcholine receptor in the CNS of Drosophila melanogaster. Interestingly, in the lobula plate labeled structures can be localized which could correspond to the large motion-sensitive tangential neurones.

Beside the role of nicotinic receptors as major mediators of central excitatory neurotransmission in insects, growing evidence exists for a functional role of muscarinic acetylcholine receptors in insects in regulating the release of acetylcholine (Hue et al., 1989; Knipper and Breer, 1989; Trimmer and Weeks, 1989; Le Corronc et al., 1991; Benson, 1992; David and Pitman,
1993; Le Corronc and Hue, 1993a). Recently published results also suggest a function of postsynaptic muscarinic receptors in modulating spike threshold in insect nerve cells (Le Corronc and Hue, 1993b; Trimmer and Weeks, 1993).

Future pharmacological work with this preparation will concentrate (i) on the further characterization of the presumed cholinergic input on the VS cells as well as on other types of tangential cells, and (ii) on the identification of other, presumably inhibitory, inputs. There is evidence that the latter play an essential role in making the response of the tangential cells more sensitive to the direction of a moving visual pattern (Egelhaaf et al., 1989; Borst and Egelhaaf, 1990; Egelhaaf et al. 1990; Haag et al. 1992). The data obtained so far seem encouraging because, the fly brain in vitro allows detailed exploration of the physiological properties of the tangential cells that underly their computational capabilities in vivo.

\section{Acknowledgements}

We are grateful to Marion Bauch for technical assistance with the photographs. This work was supported by a grant from the Max-Planck-Gesellschaft.

\section{References}

Benson, J.A. (1988) Pharmacology of a locust thoracic ganglion somal nicotinic acetylcholine receptor. In: F. Clementi (Ed.), Nicotinic Acetylcholine Receptors in the Nervous System, Springer, Heidelberg, pp. 227-240.

Benson, J.A. (1992) Electropysiolugical pharmacology of the niotinic and muscarinic cholinergic responses of isolated neuronal somata from locust thoracic ganglia. J. Exp. Biol., 170: 203-233.

Blagburn, J.M., Beadle, D.J. and Sattelle, D.B. (1985) Development of chemosensitivity of an identified insect interneurone. J. Neurosci., 5: 1167-1175.

Borst, A. and Egelhaaf, M. (1989) Principles of visual motion detection. TINS, 12: 297-306.

Borst, A. and Egelhaaf, M. (1990) Direction selectivity of blowfly motion-sensitive neurons is computed in a two-stage process. Proc. Natl. Acad. Sci. USA, 87: 9363-9367.

Borst, A. and Egelhaaf, M. (1992) In vivo imaging of calcium accumulation in fly interneurons as elicited by visual motion stimulation. Proc. Natl. Acad. Sci. USA, 89: 4139-4143.

Buchner, E. (1984) Behavioural analysis of spatial vision in insects. In: M.A. Ali (Ed.), Photoreception and Vision in Invertebrates, Plenum Press, New York, pp. 561-621.

Buchner, E., Buchner, S., Crawford, G., Mason, W.T., Salvaterra, P.M. and Sattelle, D.B. (1986) Choline acetyltransferase-like immunoreactivity in the brain of Drosophila melanogaster, Cell Tissue Res., 246: 57-62.

Callec, J.J. (1985) Synaptic transmission in the central nervous system. In: G.A. Kerkut and L.I. Gilbert (Eds.), Comprehensive Insect Physiology, Biochemistry and Pharmacology, Vol. 5, Nervous System: Structure and Motor Function, Pergamon Press, Oxford, pp. 139-179. 
Callec, J.J. and Sattelle, D.B. (1973) A simple technique for monitoring the synaptic action of pharmacological agents, I. Exp. Biol., 59: 725-738.

David, J.A. and Pitman, R.M. (1993) Activation of receptors with mixed muscarinic nicotinic pharmacology modulates a calcium current in an insect motoneuron. J. Physiol., 459: 98P.

Eckert, H. and Dvorak, D.R. (1983) The centrifugal horizontal cells in the lobula plate of the blowfly, Phaenicia sericata, J. Insect Physiol, 29: 547-560.

Edwards, F.A., Konnerth, A., Sakmann, B. and Takahashi, T. (1989) A thin slice preparation for patch clamp recordings from neurones of the mammalian central nervous system. Pflügers Arch., 414: $600-612$.

Egelhaaf, M., Hausen, K., Reichardt, W. and Wehrhahn, C. (1988) Visual course control in flies relies on neuronal computation of object and background motion, TINS, 11: 351-358.

Egelhaaf, M., Borst, A. and Reichardt, W. (1989) Computational structure of a biological motion detection system as revealed by local detector analysis in the fly's nervous system, J. Opt. Soc. Am. A, 6: 1070-1087.

Egelhaaf, M., Borst, A. and Pilz, B. (1990) The role of GABA in detecting visual motion, Brain Res., 509: 156-160.

Egelhaaf, M., Borst, A., Warzecha, A.-K., Flecks, S. and Wildemann, A. (1993) Neural circuit tuning fly visual neurons to motion of small objects. II. Input organization of inhibitory circuit elements revealed by electrophysiological and optical recording, J. Neurophysiol., 69: 340-351.

Fermi, G. and Reichardt, W. (1963) Optomotorische Reaktionen der Fliege Musca domestica. Abhängigkeit der Reaktion von der Wellenlänge, der Geschwindigkeit, dem Kontrast und der mittleren Leuchtdichte bewegter periodischer Muster, Kybernetik, 2: $15-28$.

Goodman, C.S. and Spitzer, N.C. (1980) Embryonic development of neurotransmitter receptors in grasshoppers. In: D.B. Sattelle, L.M. I Iall and J.G. Hildebrand (Eds.), Receptors for Neurotransmitters, Hormones and Pheromones in Insects, Elsevier, Amsterdam. pp. 195-207.

Gorczyca, M.G. and Hall, J.C. (1987) Immunohistochemical localization of choline acetyltransferase during development and in $\mathrm{Cha}^{\text {ts }}$ Drosophila melanogaster, J. Neurosci., 7: 1361-1369.

Götz, K.G. (1964) Optomotorische Untersuchungen des visuellen Systems einiger Augenmutanten der Fruchtfliege Drosophila, Kybernetik, 2: 77-92.

Haag, J., Egelhaaf, M. and Borst. A. (1992) Dendritic integration of motion information in visual interneurons of the blowfly, Neurosci. Lett.. 140: 173-176.

Haag, J., Egethaaf, M. and Borst, A. (1993) Active membrane properties of motion-sensitive neurons of the fly Calliphora erythrocephala. In: N. Elsner and M. Heisenberg (Eds.), Gene Brain-Behaviour, Proc. 21th Göttingen Neurobiology Conference, Thieme, Stuttgart, pp. 96

Hardie, R.C. (1989) A histamine-activated chloride channel involved in neurotransmission at a photoreceptor synapse, Nature, 339: 704-706.

Hardie, R.C. and Weckström, M. (1990) Three classes of potassium channels in large monopolar cells of the blowfly Calliphora vicina. J. Comp. Physiol. A, 167: 723-736.

Hausen, K. (1976) Functional characterization and anatomical identification of motion sensitive neurons in the lobula plate of the blowfly Calliphora erythrocephala, Z. Naturforsch., 31c: 629-633.

Hausen, K. (1982a) Motion sensitive interneurons in the optomotor system of the fly. 1 . The horizontal cells: structure and signals, Biol. Cybern., 45: 143-156.

Hausen, K. (1982b) Motion sensitive interneurons in the optomotor system of the fly. II. The horizontal cells: receptive field organization and response characteristics. Biol. Cybern., 46: 67-79.

Hausen, K. (1984) The Lobula-complex of the fly: stucture, function and significance in visual behaviour. In: M.A. Ali (Ed.), Photoreception and Vision in Invertebrates. Plenum Press. New York. pp. $523-559$.

Hengstenberg, R. (1977) Spike responses of 'non-spiking' visual interneurone, Nature, 270: $338-340$.

Hengstenberg, R. (1982a) Common visual response properties of giant vertical cells in the lobula plate of the blowfly Calliphora, $\mathrm{J}$. Comp. Physiol. A, 149: 179-193.

Hengstenberg, R. (1982b) A method of microperfusion with oxygenated saline to an insect brain, J. Neurosci. Methods, $6: 169 \ldots$ 171

Hengstenberg. R.. Hausen, K. and Hengstenberg. B. (1982) The number and structure of giant vertical cells (VS) in the lobula plate of the blowfly Calliphora erythrocephala. I. Comp. Physiol. A, $149: 163-177$.

Hue, B., Lapied, B. and Malecot, C.O. (1989) Do presynaptic muscarinic receptors regulate acetylcholine release in the central nervous system of the cockroach Periplaneta umericana. J. Exp. Biol., 142: 447-451.

Kerkut, G.A., Pilman, R.M. and Walker. R.J. (1969) Sensitivity of neurones of the insect central nervous system to iontophoretically applied acetylcholine or GABA, Nature, 222: 11775-1076

Knipper, M. and Breer. H. (1989) Muscarinic receptors modulating acetylcholine release from insect synaptosomes. Comp. Biochem. Physiol., 93C: $287-292$.

Laurent, G. (1990) Voltage-dependent nonlinearities in the membrane of locust nonspiking local interneurons, and their significance for synaptic integration, J. Neurosci., 10: 2268-2280.

Le Corronc, H., Lapied, B. and Hue, B. (1991) M2-like presynaptic receptors modulate acetylcholine release in the cockroach (Peri. planeta americana) central nervous system, J. Insect Physiol.. 37: $647-652$.

Le Corronc, H. and Hue, B. (1993a) Electrophysiological evidence for the modulation of acetylcholine-release by endogenous acetyl. choline in the cockroach central nervous svstem, J. Exp. Biol., 175: $305-310$

Le Corronc, $H$. and Hue, B. (1993b) Pharmacological and electrophysiological characterization of a postsynaptic muscarinic receptor in the central nervous system of the cockro:ch. 1. Exp. Biol. 181: 257-278.

Nässel, D.R. (1991) Neurotransmitters and neuromodulaturs in the insect visual system, Prog. Neurobiol., 37: 179-554.

Normann, T.C. (1973) Membrane potential of the corpus cardiacum neurosecretery cells of the blowfly. Calliphora snthrocephala. $J$. Insect Physiol., 19: 303-318.

Pinnock, R.D. and Sattelle. D.B. (1987) Dissociation and maintenance in vitro of neurones from adult cockroach (Periplaneta americana) and housefly (Musca domestica), I Neurosci. Meth ods, 20: 195--202.

Sattelle, D.B., McClay. A.S., Dowson, R.J. and (allec, J.J. (1976) The pharmacology of an insect ganglion: actions of carbamylcholine and acetylcholine. J. Exp. Biol. 64:13-33.

Sattelle, D.B. (1980) Acetylcholine receptors of insects. Adv. Insect Physiol., 15: 215-315.

Sattelle, D.B. (1985) Acetylcholine receptors. In: G.A. Kerkut and L.I. Gilbert (Eds.), Comprehensive Insect Physiology Biochemistry and Pharmacology, Vol. 11, Pharmacology. Pergamon Press. Oxford, pp. 395-434.

Schmid, A. (1989) Die Funktion einiger Neurotransmitter und Neuromodulatoren im Zentralnervensystem eines insekts. Dissertation, Universität Tübingen.

Schuster, R., Phannavong, B., Schroder, $C$. and Gundelfinger, E.D. (1993) Immunohistochemical localization of a ligand-binding and a structural subunit of nicotinic acetylcholine receptors in the central nervous system of Drosophila melanogaster, J. Comp. Neurol., 335: 149-162.

Shankland. D.L.. Rose, J.A. and Donniger. C. (1971 The cholinergic 
nature of the cercal nerve-giant fiber synapse in the sixth abdominal ganglion of the american cockroach Periplaneta americana (L.), J. Neurobiol., 2: 247-262.

Stewart, W.W. (1978) Functional connections between cells as revealed bye dye-coupling with a highly fluorescent naphtalimide tracer, Cell, 14: 741-759.

Strausfeld, N.J. (1989) Beneath the compound eye: neuroanatomical analysis and physiological correlates in the study of insect vision. In: D.G. Stavenga and R.C. Hardie (Eds.), Facets of Vision, Springer, Heidelberg, pp. 317-359.

Treherne, J.E. (1985) Blood-brain barrier. In: G.A. Kerkut and L.I.
Gilbert (Eds.), Comprehensive Insect Physiology Biochemistry and Pharmacology, Vol. 5, Nervous System: Structure and Motor Function, Pergamon Press, Oxford, pp. 115-137.

Trimmer, B.A. and Weeks, J.C. (1989) Effects of nicotinic and muscarinic agents on an identified motoneurone and its direct afferent inputs in larval Manduca sexta, J. Exp. Biol., 144: 303337.

Trimmer, B.A. and Weeks, J.C. (1993) Muscarinic acetyicholine-receptors modulate the excitability of an identified insect motoneurone, J. Neurophysiol., 69: 1821-1836. 